\title{
The Production of the Sequence -UI- by Francophone Learners of English
}

\author{
Jean-Paul Kouega \\ University of Yaounde I, Yaounde, Cameroon
}

\begin{abstract}
This paper considers the renderings of the sequence -UI- by Cameroonian, Gabonese, and native French users learning English with the view to finding out whether French users speaking different L1s pronounce this sequence in different or similar ways. The data were recordings of items containing -UI- and the contrastive method of analysis was used. It was found that this sequence is rendered in two ways by the learners. Besides, different L2 French-speaking learners tend to pronounce it in the same ways and so do L2 and L1 French-speaking learners. It can therefore be hypothesised that Francophone speakers tend to draw more from French when they speak English than from their respective L1s.
\end{abstract}

Keywords: L3 English learner, France, Cameroon, Gabon, consonant, vowel

\section{Introduction}

Francophone learners of English fall into the Expanding Circle of Kachru's Concentric Circles (Kachru, 1983). These learners tend to get in contact with the language via the written medium and in the process they find it difficult to keep spelling and pronunciation apart. This study sets out to check the realisations of the sequence of vowel letters $-U I$ - by these learners. This sequence is chosen because it is generally pronounced in one or two ways in French and in at least eight different ways in English. The questions underlying the exercise are as follows:

(1) How is the sequence -UI- pronounced by Francophone learners of English from Cameroon, Gabon, and France?

(2) Are there any differences between the renderings of this sequence by L2 French-using learners of English speaking different L1s?

(3) Are there any differences between the renderings of this sequence by L1 and L2 French-speaking learners of English?

The work is divided into three sections labelled review of literature, method and data collection, and results. These are considered in turn.

\section{Review of Literature}

French-medium schools all over the world are considering offering English as a compulsory subject. In

Jean-Paul Kouega, professor, Ph.D., English Language and Linguistics at University of Yaounde I, Cameroon. 
some countries like Chad and Gabon, this English subject is introduced at the secondary school level while in others like Cameroon it comes in on the first day of primary school. By the time Francophone pupils reach Terminale (Upper Sixth Form), they will have had at least six years of tuition in English. The English language production of these Francophone learners is under-researched; works on the level of phonology in particular are rare. One seminal study of this variety of English was carried out by Walter (1987). Using RP (Received Pronunciation) as a model, he examined the articulation of English vowels by French speakers and made the following eight observations:

(1) The pairs /i:/ and /I/ are merged, which causes the words "leave" and "live" to be mixed up;

(2) $/ \Lambda /$ surfaces as $/ \mathrm{a} /$ in a word like "much";

(3) /u:/ and /v/ are merged, causing the pair "pool" and "pull" to be mixed;

(4) $/ \mathfrak{p} /$ is often unrounded and, as a result, "not" sounds like "nut";

(5) / $/$ :/ and /əv/ are realised as /o/, causing "naught" and "note" to sound alike;

(6) /æ/ is realised in various ways, causing "bank" to sound like "bunk" and "pat" to surface as "pet";

(7) /eI/ is sometimes monophthongised into /e/, causing "paper" and "pepper" to be homophonous. As /æ/ may also be rendered as /e/, "mad" and "made" tend to sound alike;

(8) Other diphthongs have both their components pronounced with equal force and length, causing for example /ai/ to surface as /aji/ and /av/ to come out as /awu/.

A few researchers (Abang, 2000; Kouega, 2009; 2013; Ombouda Onana, 2010; Khan, 2012; Tagne Safotso, 2012 to name only these) have examined the vowel system of the English of francophones in Cameroon, contrasting it with that of RP English. A total of 24 oral vowels and six nasal ones were thus identified. These are listed below (see Table 1).

Table 1

Francophone English Vowel System

\begin{tabular}{|c|c|c|c|}
\hline Francophone English phonemes & Illustrative words & $\mathrm{RP}$ & Francophone English renderings \\
\hline \multicolumn{4}{|l|}{ Vowels monophthongs } \\
\hline /i/ & style & /stail/ & /stil/ \\
\hline /e/ & special & $/ \operatorname{spe} \int 1 /$ & /spesial/ \\
\hline $\mid \varepsilon /$ & dirty & /d3:tI/ & $/ \mathrm{d} \varepsilon \mathrm{ti} /$ \\
\hline$/ \mathrm{a} /$ & manage & /mænıdz/ & /manaz/ \\
\hline$/ 0 /$ & open & /əupn/ & /open/ \\
\hline /o/ & go & /gəu/ & /go/ \\
\hline$/ \mathrm{u} /$ & doubt & /daut/ & /dut/ \\
\hline$/ y /$ & bus & $/ \mathrm{b} \Lambda \mathrm{s} /$ & /bys/ \\
\hline$/ œ /$ & brother & 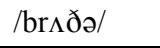 & /bRodœR/ (occasionally /bRodeR/ or /bRoda/ \\
\hline \multicolumn{4}{|l|}{ Diphthongs } \\
\hline /ie/ & nearly & /nıəli/ & /nieli/ \\
\hline /iع/ & fear & /fiə/ & /fie/ (also /fia/) \\
\hline /ia/ & diameter & /daiæmitə/ & /diameta/ (occasionally /diametœR/) \\
\hline /ij/ & interior & /Intiəriə/ & /ع̃teRið/ \\
\hline /ea/ & theatre & /Өiətə/ & /teatR/ \\
\hline /es/ & theory & /өıәгі/ & /tesRi/ \\
\hline /ae/ & aeronaut & /عərənot/ & /aeronot/ \\
\hline
\end{tabular}


(table 1 continued)

\begin{tabular}{|c|c|c|c|}
\hline Francophone English phonemes & Illustrative words & $\mathrm{RP}$ & Francophone English renderings \\
\hline \multicolumn{4}{|l|}{ Diphthongs } \\
\hline$/ \mathrm{aj} /$ & house & /haus/ & /aos/ \\
\hline /ao/ & how & /hav/ & /ao/ (also /hao/) \\
\hline /oi/ & boy & /boi/ & /boi/ \\
\hline /oa/ & boa & /bəuə/ & /boa/ \\
\hline /oe/ & toe & $/$ təu/ & /toe/ \\
\hline /uo/ & poor & /puə/ & /puo/ (also /pua/ or /pue/) \\
\hline /ya/ & usually & /ju:3əli/ & /yzuali/ \\
\hline /yع/ & cruel & /kruəl/ & /kRyel/ \\
\hline \multicolumn{4}{|l|}{ Nasal vowels } \\
\hline$/ \tilde{\varepsilon} /$ & injure & /Indza/ & $/ \tilde{\varepsilon} 3 \mathrm{yR} /$ \\
\hline$/ \tilde{\mathrm{a}} /$ & central & /sentrəl/ & /sãtRal/ \\
\hline$/ \tilde{\mathbf{z}} /$ & Monday & $/ \mathrm{m} \wedge$ ndi/ & /mõde/ \\
\hline /ĩ̃ / & television & /telıvizn/ & /televiziõ/ \\
\hline /ã̃ / & pound & /paund/ & /pã̃d/ \\
\hline 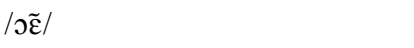 & coincide & /kəuinsaid/ & /kəz̃sid/ (occasionally /koinsid/) \\
\hline
\end{tabular}

The present study contrasts Francophone English with RP, even though it is regarded today as outdated and does no longer represent general English speech. Cruttenden (2014), for example, has used it in seven of the eight editions of his work on English pronunciation and has reported some changes in the eight edition of this same work. Similar changes are pointed out in the OED (Oxford English Dictionary) (2016). As far as this work is concerned, the symbols used to represent RP symbols are those used in the 2016 edition of the Cambridge Advanced Learner's Dictionary (2016), which combines the written transcriptions of words with their on-line oral renditions. As for the symbols used to represent the pronunciation of French, they are those of the IPA (International Phonetic Association); the variety of French targeted by the informants is that reported in the DGRC (Dictionnaire Le Grand Robert \& Collins) (2015), i.e., standard Parisian French.

\section{Method and Data Collection}

The informants for this study were contacted in Cameroon and Gabon and were selected on the basis of three criteria. First, they had to be French-speaking learners of English. Second, they had to be pupils in the class of Terminale, i.e., pupils completing secondary school level. Third, they had to have started learning English in Sixième (Form I), i.e., the first year of secondary school education, which makes the length of their exposure to English be around seven years. All pupils who did not meet these three requirements were excluded. In addition, Cameroonians who claimed not to speak an indigenous language were excluded and so were Gabonese. The L1 French informants were expatriates' children attending a French-medium secondary school in Yaounde, Cameroon. A total of 30 informants were met, 10 for each of the three groups. In short, these 30 informants had everything in common except that they had different L1 backgrounds, i.e., native French, a native Cameroonian language, and a native Gabonese language.

Between January and March 2014, these informants were contacted near their school premises by the researcher. They were taken up individually on separate occasions, usually at break time at 10 a.m. or at closing time around 3 p.m. while they were waiting for their parents to pick them up. Those who were willing to listen 
were told about the investigation and what was required of them. They were given a copy of the 46 sentences in the Appendix and were told that the reading, which was to be recorded, was to take five to ten minutes. They were asked to first read the sentences slowly to themselves and then aloud to ensure high recording quality. The tape recorder was an ordinary Sonny IPAD placed at close range. The exercise continued till the target of 10 informants for each group was attained.

\section{Results}

The sequence -UI- is rendered in English in at least nine different ways which may be grouped into four categories: monophthongs, diphthongs and triphthongs, sequences of consonant+vowel or vowel+vowel, and lastly Yod insertion. These renderings are considered in turn.

\section{-UI- Realised as a Monophthong}

This sequence of letters may be rendered by the high monophthongs /u:/ and /I/. The high back vowel /u:/ occurs in such words as "bruise", "fruit", "juice", "suitable", "suitor", and "unfruitful" to cite only these, as shown in Table 2 where Group 1 refers to pupils from Cameroon, Group 2 Gabon, and Group 3 France.

Table 2

Rendering of-UI- as /u:/

\begin{tabular}{|c|c|c|c|c|c|c|c|}
\hline \multirow[b]{2}{*}{ Words } & \multirow[b]{2}{*}{$\mathrm{RP}$} & \multicolumn{6}{|c|}{ Francophone learners' English } \\
\hline & & Group 1 & $\begin{array}{l}\mathrm{N} \\
(\%)\end{array}$ & Group 2 & $\begin{array}{l}\mathrm{N} \\
(\%)\end{array}$ & Group 3 & $\begin{array}{l}\mathrm{N} \\
(\%)\end{array}$ \\
\hline bruise & bru:z & bRuiz & $\begin{array}{l}10 \\
(100 \%)\end{array}$ & bRuiz & $\begin{array}{l}10 \\
(100 \%)\end{array}$ & bRuiz & $\begin{array}{l}10 \\
(100 \%)\end{array}$ \\
\hline fruit & fru:t & fRцi & $\begin{array}{l}10 \\
(100 \%)\end{array}$ & fRui & $\begin{array}{l}10 \\
(100 \%)\end{array}$ & fRui & $\begin{array}{l}10 \\
(100 \%)\end{array}$ \\
\hline juice & dzu:s & 3 पis & $\begin{array}{l}10 \\
(100 \%)\end{array}$ & 3 पis & $\begin{array}{l}10 \\
(100 \%)\end{array}$ & 3 पis & $\begin{array}{l}10 \\
(100 \%)\end{array}$ \\
\hline suitable & 'su:təbl & sui'teblə & $\begin{array}{l}10 \\
(100 \%)\end{array}$ & sui'teblə & $\begin{array}{l}10 \\
(100 \%)\end{array}$ & sqi'tebl & $\begin{array}{l}10 \\
(100 \%)\end{array}$ \\
\hline suitor & 'su:tə & sui'toR & $\begin{array}{l}10 \\
(100 \%)\end{array}$ & sui'toR & $\begin{array}{l}10 \\
(100 \%)\end{array}$ & sui'toR & $\begin{array}{l}10 \\
(100 \%)\end{array}$ \\
\hline unfruitful & $\Lambda n^{\prime}$ fru:tfl & ỹfRui'fyl & $\begin{array}{l}10 \\
(100 \%)\end{array}$ & ỹfRui'fyl & $\begin{array}{l}10 \\
(100 \%)\end{array}$ & ỹfRui'fyl & $\begin{array}{l}10 \\
(100 \%)\end{array}$ \\
\hline
\end{tabular}

As these renderings show, $-U I$ - is systematically pronounced by the three groups of informants as / $\mathrm{u} i /$, a sequence consisting of the semi-consonant $/ \mathrm{y} /$ followed by the oral vowel $/ \mathrm{i} /$. This can be traced back to the renderings of such French words as huile (oil), lui (him), and puits (a well), which occur in the sentences numbered 1 to 8 in the Appendix. From these renderings alone, one can claim that native French learners of English tend to draw from their L1 French when speaking English; similarly, non-native French learners of English tend to draw from their L2 French, not their respective L1s, when speaking English.

The high front vowel/I/ is used in words like "building", "guilty", "guitar", and "guinea-pig" as Table 3 shows. 
Table 3

Rendering of -UI- as /II

\begin{tabular}{|c|c|c|c|c|c|c|c|}
\hline \multirow[b]{2}{*}{ Words } & \multirow[b]{2}{*}{$\mathrm{RP}$} & \multicolumn{6}{|c|}{ Francophone learners' English } \\
\hline & & Group 1 & $\begin{array}{l}\mathrm{N} \\
(\%)\end{array}$ & Group 2 & $\begin{array}{l}\mathrm{N} \\
(\%)\end{array}$ & Group 3 & $\begin{array}{l}\mathrm{N} \\
(\%)\end{array}$ \\
\hline \multirow{2}{*}{ building } & \multirow{2}{*}{ 'bildın } & & $\begin{array}{l}8 \\
(80 \%)\end{array}$ & \multirow{2}{*}{ 'buildin } & \multirow{2}{*}{$\begin{array}{l}10 \\
(100 \%)\end{array}$} & 'buildin & $\begin{array}{l}7 \\
(70)\end{array}$ \\
\hline & & 'bildin & $\begin{array}{l}2 \\
(20 \%)\end{array}$ & & & 'bildin & $\begin{array}{l}3 \\
(30 \%)\end{array}$ \\
\hline guinea-pig & 'ginI 'pıg & 'ginea pik & $\begin{array}{l}10 \\
(100 \%)\end{array}$ & 'ginea 'pik & $\begin{array}{l}10 \\
(100 \%)\end{array}$ & 'ginea 'pik & $\begin{array}{l}10 \\
(100 \%)\end{array}$ \\
\hline guilty & 'giltI & 'gilti & $\begin{array}{l}10 \\
(100 \%)\end{array}$ & 'gilti & $\begin{array}{l}10 \\
(100 \%)\end{array}$ & 'gilti & $\begin{array}{l}10 \\
(100 \%)\end{array}$ \\
\hline guitar & gI'ta: & gi'taR & $\begin{array}{l}10 \\
(100 \%)\end{array}$ & gi'taR & $\begin{array}{l}10 \\
(100 \%)\end{array}$ & gi'taR & $\begin{array}{l}10 \\
(100 \%)\end{array}$ \\
\hline
\end{tabular}

In the word "building", -UI- tends to be replaced by the sequence / $\mathrm{q} i /$ in the speech of most Francophone learners. It is pronounced /i/ in the words "guinea-pig", "guilty", and "guitar"; this is an instance of positive transfer. Actually, the sequence of letters GUI is generally pronounced/gi/ in French, as the words guichet (counter), guide (guide), and guillemet (inverted coma) show.

\section{-UI- Realised as a Diphthong and a Triphthong}

This sequence may also be pronounced /ar/ and /arə/. It is realised as /aI/ in words like "disguise", "guide", "misguided", and "quite" as shown in Table 4.

Table 4

Rendering of-UI- as /aI/

\begin{tabular}{|c|c|c|c|c|c|c|c|}
\hline \multirow[b]{2}{*}{ Words } & \multirow[b]{2}{*}{$\mathrm{RP}$} & \multicolumn{6}{|c|}{ Francophone learners' English } \\
\hline & & Group 1 & $\begin{array}{l}\mathrm{N} \\
(\%)\end{array}$ & Group 2 & $\begin{array}{l}\mathrm{N} \\
(\%)\end{array}$ & Group 3 & $\begin{array}{l}\mathrm{N} \\
(\%)\end{array}$ \\
\hline disguise & dis'gaiz & dis'giz & $\begin{array}{l}10 \\
(100 \%)\end{array}$ & dis'giz & $\begin{array}{l}10 \\
(100 \%)\end{array}$ & dis'giz & $\begin{array}{l}10 \\
(100 \%)\end{array}$ \\
\hline guide & gard & gid & $\begin{array}{l}10 \\
(100 \%)\end{array}$ & gid & $\begin{array}{l}10 \\
(100 \%)\end{array}$ & gid & $\begin{array}{l}10 \\
(100 \%)\end{array}$ \\
\hline misguided & mis'gardid & mis'gid & $\begin{array}{l}10 \\
(100 \%)\end{array}$ & mis'gid & $\begin{array}{l}10 \\
(100 \%)\end{array}$ & mis'gid & $\begin{array}{l}10 \\
(100 \%)\end{array}$ \\
\hline unita & kwast & kwait & $\begin{array}{l}8 \\
(80 \%)\end{array}$ & kwait & $\begin{array}{l}7 \\
(70 \%)\end{array}$ & kwait & $\begin{array}{l}9 \\
(90 \%)\end{array}$ \\
\hline quite & KWdil & kwit & $\begin{array}{l}2 \\
20 \%\end{array}$ & kwit & $\begin{array}{l}3 \\
30 \%\end{array}$ & kwit & $10 \%$ \\
\hline
\end{tabular}

As can be seen, the vast majority of the learners (70 to 90\%) pronounced the -UI- sequence in the word "quite" as expected. However, this sequence is systematically rendered as /i/ instead of /aI/ in many words including "disguise", "guide", and "misguided".

-UI- is also realised as /aiə/ in "quiet", "acquire", "inquiry", and "require". In the latter three words, pre-R breaking (Wells, 1982, p. 214) is applied in RP as shown in Table 5. 
Table 5

Rendering of -UI- as /aId

\begin{tabular}{|c|c|c|c|c|c|c|c|}
\hline \multirow[b]{2}{*}{ Words } & \multirow[b]{2}{*}{$\mathrm{RP}$} & \multicolumn{6}{|c|}{ Francophone learners' English } \\
\hline & & Group 1 & $\begin{array}{l}\mathrm{N} \\
(\%)\end{array}$ & Group 2 & $\begin{array}{l}\mathrm{N} \\
(\%)\end{array}$ & Group 3 & $\begin{array}{l}\mathrm{N} \\
(\%)\end{array}$ \\
\hline \multirow{2}{*}{ quiet } & \multirow{2}{*}{ kwaiət } & kwajet & $\begin{array}{l}9 \\
(90 \%)\end{array}$ & kwajet & $\begin{array}{l}8 \\
(80 \%)\end{array}$ & kwajet & $\begin{array}{l}8 \\
(80 \%)\end{array}$ \\
\hline & & kict & $\begin{array}{l}1 \\
10 \%\end{array}$ & kict & $\begin{array}{l}2 \\
(20 \%)\end{array}$ & kict & $\begin{array}{l}2 \\
(20 \%)\end{array}$ \\
\hline acquire & ə'kwaiə & a'kwaja & $\begin{array}{l}10 \\
(100 \%)\end{array}$ & a'kwaja & $\begin{array}{l}10 \\
(100 \%)\end{array}$ & a'kwaja & $\begin{array}{l}10 \\
(100 \%)\end{array}$ \\
\hline inquiry & In'kwaiərI & 'ẼkwaRi & $\begin{array}{l}10 \\
(100 \%)\end{array}$ & 'ẼkwaRi & $\begin{array}{l}10 \\
(100 \%)\end{array}$ & 'ẼkwaRi & $\begin{array}{l}10 \\
(100 \%)\end{array}$ \\
\hline require & rI'kwaiə & Ri'kwaja & $\begin{array}{l}10 \\
(100 \%)\end{array}$ & Ri'kwaja & $\begin{array}{l}10 \\
(100 \%)\end{array}$ & Ri'kwaja & $\begin{array}{l}10 \\
(100 \%)\end{array}$ \\
\hline
\end{tabular}

The word "quiet" tends to be pronounced in two ways, i.e., /kwajet/ and /kict/. In the first rendering, the triphthong /aIə/ is targeted but the sequence /aje/ is attained whereas in the second rendering, spelling pronunciation causes the foreign diphthong /ie/ to surface. In the words "acquire" and "require", the triphthong /arə/ is realised as /aja/. Interestingly, /arə/ in the word "inquiry" is monophthongised to /a/.

\section{-UI- Realised as a Sequence of Consonant+Vowel or Vowel+Vowel}

The combination -UI- may be rendered as /wI/ and /u:I/. First, it is usually pronounced /wI/ (consonant+vowel) when preceded by the velars /g/ as in "anguish", /k/ as in "quick", or by the fricative /s/ as in "suite". Other combinations beginning with $U$ like $-U A$ - in "persuade" behave the same.

Table 6

Rendering of -UI- as /wI/

\begin{tabular}{|c|c|c|c|c|c|c|c|}
\hline \multirow[b]{2}{*}{ Words } & \multirow[b]{2}{*}{$\mathrm{RP}$} & \multicolumn{6}{|c|}{ Francophone learners' English } \\
\hline & & Group 1 & $\begin{array}{l}\mathrm{N} \\
(\%)\end{array}$ & Group 2 & $\begin{array}{l}\mathrm{N} \\
(\%)\end{array}$ & Group 3 & $\begin{array}{l}\mathrm{N} \\
(\%)\end{array}$ \\
\hline anguish & 'æygwis & ã'gif & $\begin{array}{l}10 \\
(100 \%)\end{array}$ & â'gif & $\begin{array}{l}10 \\
(100 \%)\end{array}$ & ã'gif & $\begin{array}{l}10 \\
(100 \%)\end{array}$ \\
\hline suite & swi:t & 'suitə & $\begin{array}{l}10 \\
(100 \%)\end{array}$ & 'suitə & $\begin{array}{l}10 \\
(100 \%)\end{array}$ & syit & $\begin{array}{l}10 \\
(100 \%)\end{array}$ \\
\hline quick & kwIk & kwik & $\begin{array}{l}10 \\
(100 \%)\end{array}$ & kwik & $\begin{array}{l}10 \\
(100 \%)\end{array}$ & kwik & $\begin{array}{l}10 \\
(100 \%)\end{array}$ \\
\hline equip & I'kwip & e'kip & $\begin{array}{l}10 \\
(100 \%)\end{array}$ & e'kip & $\begin{array}{l}10 \\
(100 \%)\end{array}$ & e'kip & $\begin{array}{l}10 \\
(100 \%)\end{array}$ \\
\hline squirrel & 'skwIrəl & 'skiRel & $\begin{array}{l}10 \\
(100 \%)\end{array}$ & 'skiRel & $\begin{array}{l}10 \\
(100 \%)\end{array}$ & 'skiRel & $\begin{array}{l}10 \\
(100 \%)\end{array}$ \\
\hline liquid & 'Irkwid & li'kid & $\begin{array}{l}10 \\
(100 \%)\end{array}$ & li'kid & $\begin{array}{l}10 \\
(100 \%)\end{array}$ & li'kid & $\begin{array}{l}10 \\
(100 \%)\end{array}$ \\
\hline prerequisite & $\begin{array}{l}\text { prI'rekwI } \\
\text { zIt }\end{array}$ & $\begin{array}{l}\text { pReRe } \\
\text { ki'zit }\end{array}$ & $\begin{array}{l}10 \\
(100 \%)\end{array}$ & $\begin{array}{l}\text { pReRe } \\
\text { ki'zit }\end{array}$ & $\begin{array}{l}10 \\
(100 \%)\end{array}$ & $\begin{array}{l}\text { pReRe } \\
\text { ki'zit }\end{array}$ & $\begin{array}{l}10 \\
(100 \%)\end{array}$ \\
\hline
\end{tabular}

In the speech of francophones, $\mathrm{RP} / \mathrm{wi} /$ is pronounced /i/ when - UI- is preceded by a velar like /g/ as in "anguish" or /k/ as in "equip" and "liquid". Other words that fall into this category but were not tested include: "equivalence", "inquisitive", "quintessence", "quit", "colloquial”, and "acquit". Needless to say, this negative transfer can be traced back to French, as the words équiper (to equip) and liquide (liquid) show. An exception to this observation is the word "quick", which is pronounced as expected. Interestingly, /wi/ is replaced by / $\mathrm{yi}$ / in 
"suite", a French sound sequence occurring in words like lui (him) or puits (a well).

Secondly, -UI- is pronounced /u:I/, a vowel+vowel sequence consisting of two consecutive monophthongs, as can be seen in the word "Hinduism" in Table 7.

Table 7

Rendering of -UI- as /u:I/

\begin{tabular}{|c|c|c|c|c|c|c|c|}
\hline \multirow[b]{2}{*}{ Words } & \multirow[b]{2}{*}{$\mathrm{RP}$} & \multicolumn{6}{|c|}{ Francophone learners' English } \\
\hline & & Group 1 & $\begin{array}{l}\mathrm{N} \\
(\%)\end{array}$ & Group 2 & $\begin{array}{l}\mathrm{N} \\
(\%)\end{array}$ & Group 3 & $\begin{array}{l}\mathrm{N} \\
(\%)\end{array}$ \\
\hline Hinduism & 'hindu:Izm & $\tilde{\varepsilon}^{\prime}$ duismə & $\begin{array}{l}10 \\
(100 \%)\end{array}$ & $\tilde{\varepsilon}^{\prime}$ duismə & $\begin{array}{l}10 \\
(100 \%)\end{array}$ & $\tilde{\varepsilon}^{\prime}$ duism & $\begin{array}{l}10 \\
(100 \%)\end{array}$ \\
\hline bluish & 'blu:I & 'bluis & $\begin{array}{l}10 \\
(100 \%)\end{array}$ & 'bluis & $\begin{array}{l}10 \\
(100 \%)\end{array}$ & 'bluis & $\begin{array}{l}10 \\
(100 \%)\end{array}$ \\
\hline altruist & 'æltru:Ist & al'tRyistə & $\begin{array}{l}10 \\
(100 \%)\end{array}$ & al'tRuistə & $\begin{array}{l}10 \\
(100 \%)\end{array}$ & al'tRyist & $\begin{array}{l}10 \\
(100 \%)\end{array}$ \\
\hline fluid & 'flu:Id & 'fluidə & $\begin{array}{l}10 \\
(100 \%)\end{array}$ & 'fluidə & $\begin{array}{l}10 \\
(100 \%)\end{array}$ & 'flyid & $\begin{array}{l}10 \\
(100 \%)\end{array}$ \\
\hline ruin & 'ru:In & 'Ruinə & $\begin{array}{l}10 \\
(100 \%)\end{array}$ & 'Ruinə & $\begin{array}{l}10 \\
(100 \%)\end{array}$ & 'Ruin & $\begin{array}{l}10 \\
(100 \%)\end{array}$ \\
\hline truism & 'tru:Izm & 'tRyismə & $\begin{array}{l}10 \\
(100 \%)\end{array}$ & 'tRyismə & $\begin{array}{l}10 \\
(100 \%)\end{array}$ & 'tRyism & $\begin{array}{l}10 \\
(100 \%)\end{array}$ \\
\hline
\end{tabular}

The rendering by the informants of /u:I/ as /ui/ in "Hinduism" does not pose any serious problem of recognition of the word; this can be regarded as a good case of positive transfer. However, /u:I/ rendered as / $\mathrm{u} i /$, a sequence of two French sounds, is a real case of negative transfer. As a result, the renderings of words like "bluish", "altruist", "fluid", and "ruin" cause these words to sound strange if at all they are recognised. The same can be said of the rendering of /u:i/ as /yi/ in "truism".

\section{-UI- Realised With the Yod}

In medial position, the letter - $U$ - together with the vowel letters with which it combines tends to be pronounced with the Yod when it is preceded by consonants like /p, b, t, d, k, g, f, z, h, l, n/ as in the words "stipulate", "butane", "tumult", "reduce", “cube”, "singular", "refuse", "usurious", "human", "volume”, and "venue". Regarding -UI-, it is generally rendered as /ju:/ as in "nuisance", /ju:I/ as in "intuition”, and /ju:ə/ as in "annuity" and other words in Table 8.

Table 8

Rendering of -UI-With the Yod

\begin{tabular}{|c|c|c|c|c|c|c|c|}
\hline \multirow[b]{2}{*}{ Words } & \multirow[b]{2}{*}{$\mathrm{RP}$} & \multicolumn{6}{|c|}{ Francophone learners' English } \\
\hline & & Group 1 & $\begin{array}{l}\mathrm{N} \\
(\%)\end{array}$ & Group 2 & $\begin{array}{l}\mathrm{N} \\
(\%)\end{array}$ & Group 3 & $\begin{array}{l}\mathrm{N} \\
(\%)\end{array}$ \\
\hline nuisance & 'nju:sns & nyi'zãs & $\begin{array}{l}10 \\
(100 \%)\end{array}$ & nyi'zãs & $\begin{array}{l}10 \\
(100 \%)\end{array}$ & nui'zãs & $\begin{array}{l}10 \\
(100 \%)\end{array}$ \\
\hline arguing & 'a:gju:ın & aR'gui & $\begin{array}{l}10 \\
(100 \%)\end{array}$ & aR'gui & $\begin{array}{l}10 \\
(100 \%)\end{array}$ & aR'gui & $\begin{array}{l}10 \\
(100 \%)\end{array}$ \\
\hline fortuitous & fo:'tju:Itəs & foRtui'tos & $\begin{array}{l}10 \\
(100 \%)\end{array}$ & foRtui'tos & $\begin{array}{l}10 \\
(100 \%)\end{array}$ & foRtui'tos & $\begin{array}{l}10 \\
(100 \%)\end{array}$ \\
\hline intuition & In'tju:I $\int n$ & عีtui'sjõ & $\begin{array}{l}10 \\
(100 \%)\end{array}$ & عtui'sjõ & $\begin{array}{l}10 \\
(100 \%)\end{array}$ & ع̃tui'sjõ & $\begin{array}{l}10 \\
(100 \%)\end{array}$ \\
\hline \multirow{2}{*}{ suicide } & \multirow{2}{*}{ 'sju:Isaid } & syi'said & $\begin{array}{l}8 \\
(80 \%)\end{array}$ & syi'said & $\begin{array}{l}6 \\
(60 \%)\end{array}$ & syi'said & $\begin{array}{l}7 \\
(70 \%)\end{array}$ \\
\hline & & sui'sidə & $\begin{array}{l}2 \\
(20 \%)\end{array}$ & sui'sidə & $\begin{array}{l}4 \\
(40 \%)\end{array}$ & sui'sid & $\begin{array}{l}3 \\
(30 \%)\end{array}$ \\
\hline
\end{tabular}


(table 8 continued)

\begin{tabular}{|c|c|c|c|c|c|c|c|}
\hline \multirow[b]{2}{*}{ Words } & \multirow[b]{2}{*}{$\mathrm{RP}$} & \multicolumn{6}{|c|}{ Francophone learners' English } \\
\hline & & Group 1 & $\begin{array}{l}\mathrm{N} \\
(\%)\end{array}$ & Group 2 & $\begin{array}{l}\mathrm{N} \\
(\%)\end{array}$ & Group 3 & $\begin{array}{l}\mathrm{N} \\
(\%)\end{array}$ \\
\hline annuity & ə'nju:ətI & anyi'ti & $\begin{array}{l}10 \\
(100 \%)\end{array}$ & anyi'ti & $\begin{array}{l}10 \\
(100 \%)\end{array}$ & anyi'ti & $\begin{array}{l}10 \\
(100 \%)\end{array}$ \\
\hline assiduity & æsı'dju:ətı & asidui'ti & $\begin{array}{l}10 \\
(100 \%)\end{array}$ & asidui'ti & $\begin{array}{l}10 \\
(100 \%)\end{array}$ & asidui'ti & $\begin{array}{l}10 \\
(100 \%)\end{array}$ \\
\hline exiguity & EgzI'gju:ətI & Egzigui' ti & $\begin{array}{l}10 \\
(100 \%)\end{array}$ & Egzigy'iti & $\begin{array}{l}10 \\
(100 \%)\end{array}$ & egzigy'iti & $\begin{array}{l}10 \\
(100 \%)\end{array}$ \\
\hline
\end{tabular}

When the Yod is expected, -UI- is systematically rendered as / $\mathrm{u} \mathrm{i} /$, a sequence of sounds occurring in French words like lui (him) and puits (a well). This is a case of negative transfer.

\section{Conclusion and Implications}

Three questions were set to guide this study. The first one ran as follows: How is the sequence -UIpronounced by Francophone learners of English from Cameroon, Gabon, and France? This sequence was found to be generally pronounced /i/ as in "guilty", / $\mathrm{i}$ / as in "nuisance", /ui/ as in "Hinduism", and /wi/ as in "quick" by the three groups of learners. The second question checked whether there were any differences in the renderings of the sequence -UI- by L2 French-using learners of English speaking different L1s. Throughout the analysis, no marked difference was observed in the renderings of Group 1 and Group 2 French-using learners who spoke different L1s. Lastly, Question 3 asked whether there were any differences between the renderings of this sequence by L1 and L2 French-speaking learners of English. The analysis showed no significant difference in the renderings of this sequence by L1 and L2 French-speaking learners of English.

From these observations, two possible hypotheses can be set up to guide future research. First, L2 speakers of French generally draw from French when they learn English and not from their respective L1s. Second, both L1 and L2 speakers of French draw from this language when learning English. This finding is of broad interest to scholars in L3 English in francophone contexts. Today, many francophone countries are introducing English in their systems of education and it is unlikely that many varieties of francophone English would emerge, as similar features are likely to be found in most potential varieties. To put it in other terms, Chadian, Gabonese, Cameroonian, Senegalese, and Ivorian varieties of learner Englishes will share many features with native French learner English. For this reason, it would be appropriate to use the lone term "francophone English" to refer to them all.

\section{References}

Abang, R. N. (2000). The teaching of English in francophone primary schools: A phonological perspective. (Unpublished "maitrise" dissertation, University of Yaounde I).

CALD (The Cambridge Advanced Learner's Dictionary) (4th ed.). (2016). Cambridge: Cambridge University Press. Retrieved from on-line version at http://dictionary.cambridge.org

Cruttenden, A. (2014). Gimson's pronunciation of English (8th ed.). Cambridge: Routledge (Taylor and Francis).

DGRC (Dictionnaire Le Grand Robert \& Collins). (2015). Paris: Dictionnaires Le Robert.

Kachru, B. B. (1983). The Indianization of English: The English language in India. Delhi: Oxford University Press.

Khan, M. A. (2012). Some aspects of the English pronunciation of level IV bilingual francophone student-teachers of the ENS Yaoundé. ( II dissertation, ENS Yaoundé). 
Kouega, J. P. (2009). The English of francophone users in Cameroon: A phonological appraisal. Annals of the Faculty of Arts, Letters and Social Sciences, Special Edition: Festschrift in honour of Professor Paul N. Mbangwana, 109-120.

Kouega, J. P. (2013). Camfranglais: A glossary of common words, phrases and usages. Muenchen, Germany: Lincom Europa. OED (The Oxford English Dictionary). (2016). Retrieved December 15, 2015 from online at http://public.oed.com/

Ombouda Onana, E. (2010). The oral performance of francophone learners of English: A case study conducted in the Department of Bilingual Studies, University of Yaounde I. (Unpublished master's thesis, University of Yaounde I).

Tagne Safotso, G. (2012). Aspects of Cameroon francophone English (CamFE) phonology. Theory and Practice in Language Studies, 2(12), 2471-2477.

Walter, C. (1987). French speakers. In M. Swan and B. Smith (Eds.), Learner English: A teacher guide to interference and other problems (pp. 42-57). Cambridge: CUP.

Wells, J. C. (1982). Accents of English. Cambridge: CUP.

\section{Appendix}

Questionnaire

I am a researcher interested in examining the use of English in French-medium schools. Could you help me to pick out an Upper Sixth pupil (Terminale). I will ask this pupil to answer the two questions below and read the 46 sentences that follow.

1. Are you in Upper Sixth? Are you in Terminale?

2. Do you speak any Cameroonian language? Do you speak any Gabonese language? If yes, what is this language called or what is the main locality where it is spoken?

3. What class were you in when you started learning English in your school?

Exercises

Please do the two exercises below.

Exercise I

Read the French sentences in the left column and their near equivalents in the right column. Begin with the number preceding each of them

\begin{tabular}{|l|l|l|}
\hline 1 & Donne-lui un peu d'huile! & Give him a little oil! \\
\hline 2. & L'eau de ce puits est-elle propre? & Is the water from this well clean? \\
\hline 3. & Qui le lui a dit? & Who told him? \\
\hline 4. & La linguistique est-elle une science exacte? & Is linguistics a pure science? \\
\hline 5. & Il a besoin d'argent liquide & He needs some liquid money. \\
\hline 6. & Voila un fruit mûr! & That is a ripe fruit. \\
\hline 7. & Où est la quittance? & Where is the quittance? \\
\hline 8. & Il y aura une messe de requiem. & There will be a requiem mass. \\
\hline
\end{tabular}


Exercise II

Read each of the words below and the sentence next to it. Begin with the number preceding it

\begin{tabular}{|c|c|c|}
\hline 9. & anguish & Don't talk to her now; she is in anguish. \\
\hline 10. & annuity & His resources are in an annuity. \\
\hline 11. & arguing (to argue) & Stop arguing! \\
\hline 12 & bluish & The dress is bluish in colour. \\
\hline 13. & bruise & Beware: you may bruise your leg. \\
\hline 14. & building & He lives in a tall building. \\
\hline 15. & disguise & He entered the dormitory in the disguise of a girl with fat breasts. \\
\hline 16. & equip & They will equip the laboratory next week. \\
\hline 17. & guide & Use this model as a guide! \\
\hline 18. & guilty & He was found guilty. \\
\hline 19. & guitarist & Are there any guitarists in your school? \\
\hline 20. & juice & There is some fruit juice in the fridge. \\
\hline 21. & squirrel & There is a squirrel on that tree. \\
\hline 22. & acquire & He has acquired a good handwriting. \\
\hline 23. & fluid & Is water a fluid substance? \\
\hline 24. & altruist & He works to make other people happy; he is altruist. \\
\hline 25. & annuity & They live on an annuity. \\
\hline 26. & assiduity & Assiduity does not pay if you are working for an irresponsible man. \\
\hline 27. & exiguity & The problem with that room is its exiguity. \\
\hline 28. & fortuitous & It was a fortuitous occasion as it was not planned. \\
\hline 29. & guinea-pig & How could the guinea-pig get out of this box? \\
\hline 30. & Hinduism & Hinduism is widespread in India. \\
\hline 31. & inquiry & Do you want to organise an inquiry session on the matter? \\
\hline 32. & intuition & Your intuition does not work well all the time. \\
\hline 33. & misguided (to misguide) & Just forgive him; he was misguided. \\
\hline 34. & nuisance & That man is a real nuisance \\
\hline 35. & quick & Let us have a quick talk! \\
\hline 36. & quiet & We had a quiet day with the children. \\
\hline 37. & quite & It was quite an interesting film. \\
\hline 38. & require & Does the child's situation require my presence in school now? \\
\hline 39. & prerequisite & Being literate is a prerequisite for taking a driving test. \\
\hline 40. & ruin & What ruined him was drinking. \\
\hline 41. & suicide & It was not a suicide; he was killed. \\
\hline 42. & suitable & The weather is suitable today. \\
\hline 43. & suitor & Presently, she has 5 suitors and her friend has none. \\
\hline 44. & suite & There are three suites in that hotel. \\
\hline 45. & truism & It is a truism to say that mangoes get ripe in June. \\
\hline 46. & unfruitful & The search was unfruitful; nothing was found. \\
\hline
\end{tabular}

